\title{
Slum Housing Conditions and Eradication Practices in Some Selected Nigerian Cities
}

\author{
Mallo Maren Daniel ${ }^{1}$, Samuel Danjuma Wapwera ${ }^{2}$, Esther Mamman Akande $^{1}$, Choji Christopher Musa $^{2}$ \& Aliyu \\ Ahmad Aliyu $^{3}$ \\ ${ }^{1}$ Department of Building, Faculty of Environmental Sciences, University of Jos, Nigeria \\ ${ }^{2}$ Department of Urban and Regional Planning, Faculty of Environmental Sciences, University of Jos, Nigeria \\ ${ }^{3}$ Estate Management Programme, School of Environmental Sciences, Abubakar Tafawa Balewa University, \\ Bauchi, Nigeria
}

Correspondence: Mallo Maren Daniel, Department of Building, Faculty of Environmental Sciences, University of Jos, PMB 2084, Jos, Nigeria. Tel: 234-70-3505-5667. E-mail: mallod@unijos.edu.ng; marenmallodaniel@gmail.com

Received: November 20, 2014 Accepted: January 15, 2015 Online Published: March 30, 2015

doi:10.5539/jsd.v8n2p230

URL: http://dx.doi.org/10.5539/jsd.v8n2p230

\begin{abstract}
This paper reviews the state of urban slums in Nigeria and attempts to explicate the issues that arise from the approach of slum eradication in some selected cities (Lagos, Port Harcourt, Abuja and Jos). A wide range of secondary source material was collected and analysed thematically. The analysis affirms that the slumming process in the four cities is significantly accounted for, by rising urbanisation. In Lagos and Port Harcourt cities the urbanisation appears to be linked to the industrialisation process but this is not the case in Abuja and Jos. However, some factors were found to be common in the slumming process of the four cities such as: One, the rising population which is increasing the demand for urban services. Two, there is acute shortage in the supply of adequate housing for the low-come and poor households. Lastly, there is inadequate arrangement for the effective management of urban growth and expansion. Other issues identified are: the absence of mechanisms for the prevention of slum formation; a preference for the demolition of slums by authorities as opposed to their improvement; a wide practice of implementing eviction on short notice; and in most instances, government authorities have failed to provide adequate alternative shelter to evicted households. These findings clearly indicate that the subsisting housing and urban development policies leave gaps for such flawed practices. Accordingly, policy recommendations and suggestions for empirical study are made.
\end{abstract}

Keywords: slums, housing, slums eradication, force eviction, slum demolition

\section{Introduction}

This paper reviews the state of urban slums in Nigeria as a whole, and the issues that arise from the approach to slum eradication in some selected cities - Lagos, Port Harcourt, Abuja and Jos. The study is especially concern with the attempts to eradicate slums by government authorities, the issues that arise and their policy implication. Slumming conditions have become a global concern and one key factor that is driving such development is rapid urbanisation. Rapid urbanisation is now a global concern and Davis $(20045,6)$ in his paper - Planet of Slums captured the problem: one, that the earth has urbanised even faster than originally predicted by Thomas Malthus in 1972. For instance, there were 86 cities in the world in 1950 with a population over one million. Today, there are about 550 cities; two, cities are growing phenomenally and have now absorbed nearly two-thirds of the global population. And, indeed, the urban population (3.2 billion) as of 2006 was already larger than the total population of the world in 1960; three, the global country side was estimated at 3.2 billion in 2006 . This has been shrinking and it is anticipated that this will continue in such a manner that cities would account for about 10 billion of the world's population in 2050; finally, by 2050, it is anticipated that 95 per cent of the world's population will reside in the urban areas of the developing countries.

Accordingly, the developing countries will face a crisis of urbanisation. Indeed, the crisis is already manifesting in the sub-Sahara African region where countries are faced with the shortage of good housing, urban infrastructure deficiency, urban poverty (Habitat International Coalition - HIC, 2006 p.13; 2009 p.14), growing 
urban populations, prevalence of informal housing practices and poor housing conditions (International Housing Coalition, 2009 p.11). The urban population is rising (see Table One) among the sub-Sahara African countries; already, between 75 and 99 percent of urban residents in many African cities live in squalid slums of ramshackle housing (IHC, 2006 p.13; 2007 p. 11). Further, the urbanisation experience in Africa is creating hardship for urban residents as it appears not to have a positive relationship with the economic growth. This is contrary to the experience of urbanisation in today's developed world over the nineteenth century. Evidence (Diniejko, 2012; Davis, 2004 \& 2006; Baker, 2001) suggest that the nineteenth century experiences of urbanisation in today's developed nations (such as Britain and USA) were linked to the industrial revolution. Essentially, the industrialisation process was seen to bring about urbanisation and rising urban population, and slumming was inextricably linked to these. On the contrary, the experience in the developing countries is that of a rising urbanisation and slumming without much industrialisation occurring (Davis, 2004).

Table 1. Population, urbanisation and poverty in sub-Saharan Africa

\begin{tabular}{llccl}
\hline Countries & $\begin{array}{l}\text { Population in } \\
\text { millions }(2010)\end{array}$ & $\begin{array}{l}\text { Urban population as \% } \\
\text { of total }(2009)\end{array}$ & $\begin{array}{l}\text { Population less than } \\
\text { US\$2 per day (2009) }\end{array}$ & $\begin{array}{l}\text { Population below } \\
\text { national poverty line }\end{array}$ \\
\hline Angola & 18.9 & 57.6 & 70.2 & $68.0(2008)$ \\
Benin & 9.2 & 41.6 & 75.3 & $29.0(1999)$ \\
Botswana & 1.9 & 60.4 & 49.4 & $30.3(2003)$ \\
Ethiopia & 84.9 & 17.2 & 77.6 & $44.2(2000)$ \\
Ghana & 24.3 & 50.7 & 53.6 & $28.5(2006)$ \\
Kenya & 40.8 & 21.9 & 39.9 & $45.9(2006)$ \\
Namibia & 2.2 & 37.4 & 62.2 & Not available \\
Nigeria & 158.3 & 49.1 & 83.9 & $65.6(1996)$ \\
South & 50.4 & 61.2 & 42.9 & $45.0(2000)$ \\
Africa & & & & \\
Tanzania & 45.0 & 25.9 & 96.6 & $35.7(2001)$ \\
\hline Source: Fin
\end{tabular}

Source: FinMark Trust Year Book (2011)

In a global perspective, the number of people that are affected by slum conditions has been on the rise, from 777 million in 2000 to almost 830 million in 2010 (United Nations, 2013). At the sub-continental level, the sub-Sahara Africa was said to have approximately 200 million slum dwellers. During this period, there were 11.8 million slums dwellers in the North Africa region. In Asia, the statistics revealed a figure of 190.7 million for Southern Asia, 189.6 million for Eastern Asia, 88.9 million for South-Eastern Asia and 35 million for the Western Asia region. In Latin America and the Caribbean, there were 110.7 million slum dwellers and in the region of Oceania, there were six million (UN-Habitat, 2010). These figures are quite disturbing and are corroborative of the assertion that the world is indeed a planet of slums (Davis, $2004 \& 2006$ ).

In sub-Saharan Africa, slums are a consequence of unrealistic regulatory frameworks, ill-conceived policies, inadequate urban planning, and weak institutional capacity (World Bank, 2008). Other factors include: rapid rural-to-urban migration, increasing urban poverty and inequality, insecure tenure, and globalisation (UN-Habitat, 2007).The slums are also found to arise from failed policies, bad governance, corruption, inappropriate regulation, dysfunctional land markets, unresponsive financial systems, and a fundamental lack of political will (Chang, 2009 citing Cities Alliance, 2000). And to a high degree, there is a correlation between urbanisation and slum formation in most developing countries (Akinbamijo, 2012; Ooi and Phua, 2007). Contrary to these acclaimed reasons, neoliberalism, especially the IMF's Structural Adjustment Programme (SAP) has been squarely indicted. Davis (2006 p.11), one of the leading critiques of SAP argues: "the primary direction of both national and international interventions during the last twenty years has actually increased urban poverty and slums, increased exclusion and inequality, and weakened urban elites in their efforts to use cities as engines of growth"

Writing about the rising urbanisation in developing countries, Venard (1995) speculates that in 2020, Africa will have mega-cities with 5 million inhabitants or more. This rapid growth in urban population would lead to rapid 
growth both in the size and number of urban places. Recent developments in Nigeria are making right, Venard's forecast, and based on a census that was conducted in 2006, five (Lagos, Kano, Port-Harcourt, Oyo, Kaduna and Katsina) of cities in Nigeria recorded a population above 5million and 20 recorded a population of 3 to 5 million inhabitants (FRN-NPC, 2010). The rising urbanisation in Nigerian cities coupled with a shortage of good housing is worsening the housing conditions of urban poor. In Tables 2, for instance, the percentage of households using unsafe water from unprotected sources as of 2011 was over 30 percent. These water sources comprised of Well and spring (14.3 percent); tank truck/ cart and small tank (4.0 percent) and surface sources (river/lake/pond/stream/dam) (15.3 percent).

Table 2. Sources of water for domestic used in Nigeria's urban and rural areas as of 2011

\begin{tabular}{lccc}
\hline Characteristics of water supply sources & \multicolumn{3}{c}{ Percentage } \\
\cline { 2 - 4 } & Urban & Rural & National \\
\hline Pipe into dwelling & 16.9 & 3.4 & 8.7 \\
Pipe to yard/plot & 3.7 & 3.2 & 3.4 \\
Public tap/stand pipe & - & - & - \\
Borehole & 39.8 & 30.9 & 34.4 \\
Protected well / spring & 18.2 & 15.7 & 16.7 \\
Rain water & 0.7 & 1.2 & 1.0 \\
Bottled water & 6.0 & 1.3 & 3.2 \\
Unprotected well / spring & 5.1 & 20.2 & 14.3 \\
Tank truck / cart \& small tank & 5.5 & 3.1 & 4.0 \\
Surface water (river/lake/pond/stream/dam) & 4.7 & 22.3 & 15.3 \\
Others & 6.0 & 1.3 & 3.2 \\
Total & $\mathbf{1 0 0 . 0}$ & $\mathbf{1 0 0 . 0}$ & $\mathbf{1 0 0 . 0}$ \\
\hline
\end{tabular}

Source: FRN - National Bureau of Statistics (2012 p. 39, 40).

In like manner, Tables 3 confirms that less than 20 percent of households were using standard toilet facilities (such as flush to sewage - 4.7 percent; and flush to septic tank - 14.2 percent). Considerable households (19.0 percent) did not have any toilet provision and majority had toilets facilities that were considered substandard: uncovered Latrine (12.2 percent); covered pit Latrine (36.1 percent); Pail / Bucket (0.8 percent) and toilet facility constructed on water (2.9 percent).

Table 3.Toilet facilities used by households in Nigeria's urban and rural areas as of 2011

\begin{tabular}{lccc}
\hline Characteristics of toilet facilities & \multicolumn{3}{c}{ Percentage } \\
\cline { 2 - 4 } & Urban & Rural & National \\
\hline No toilet provision & 12.5 & 23.3 & 19.0 \\
Toilet constructed on water & 3.5 & 2.5 & 2.9 \\
Flush to sewage & 9.4 & 1.6 & 4.7 \\
Flush to septic tank & 28.0 & 5.2 & 14.2 \\
Pail / Bucket & 0.3 & 1.1 & 0.8 \\
Covered pit Latrine & 33.8 & 37.6 & 36.1 \\
Ventilated Improved Pit (VIP) Latrine & 2.1 & 3.1 & 2.7 \\
Uncovered Latrine & 8.5 & 14.6 & 12.2 \\
Others & 1.9 & 11.0 & 7.4 \\
Total & $\mathbf{1 0 0 . 0}$ & $\mathbf{1 0 0 . 0}$ & $\mathbf{1 0 0 . 0}$ \\
\hline
\end{tabular}

Source: National Bureau of Statistics (2012 p. 39). 
Furthermore, the current urbanisation rate of Nigeria is 5.5 percent per annum and the urban population was put at 50 percent in 2012 (Pepple, 2012a). The UN-HABITAT (2008) reports that Nigeria's inability to plan and manage rapid urbanisation has resulted in uncontrollable growth in the entire major cities and towns. This is leading to a decay of inner cities and the growth of shanty towns, especially in the peri-urban areas. The burden of these problems is borne by the poor people and the low income groups who lack the financial capacity to access adequate housing. A recent projection indicates that more than 60 percent of Nigerians will live in urban centres by 2025 , and a sizeable proportion (mostly low-income earners and the poor) of these are likely to live in slums if action is not taken (FGN - MDG Report, 2010). The slum situation in Nigeria is already frightening for the reason that the proportion of people affected by slum conditions is such a significant element in sub-Sahara Africa. In 2012, the estimated population of 47 sub-Sahara African countries was 910.4million (World Bank, 2013) and of this, 167million were Nigerians (FRN-National Population Commission, 2013). Of the 167million people in Nigeria, 61.1 percent were said to reside in slums (Pepple, 2012a). Mathematically, 61.1 percent of 167 million is equal to 102.203 million and from this, it can be inferred that Nigeria alone has over half of the 200million slum dwellers in sub-Sahara Africa. This situation calls for appropriate policy and response by the authorities in Nigeria.

\section{Objectives of the Study, Approach and Data}

The motivation for this study stems from the documented criticisms (see for example, SERAC, 2006; COHRE, 2008; Amnesty International, 2010 \& 2011; and Agbola and Jinadu, 1997) about the approach to slum eradication in Nigeria and the study is designed to pursue a number of objectives: firstly, to undertake a brief review of the place of slums in the development of cities. Secondly, to examine the dimensions of urban slums and issues that confronts slums dwellers in Nigeria. Lastly, to explicate the approach to slums eradication in Nigeria, to identify issues that arises from the practices and to examine their policy implication. In conducting the study, slums problems and response of governmental authorities are illustrated with relevant examples from Lagos, the commercial centre of Nigeria and most urbanising city in Africa (Potts, 2010 pp. 13-14), Abuja, the newest city and the Federal Capital Territory (FCT), Port-Harcourt, an industrial city and a commercial centre and Jos, a moderately urbanising city. The slum problems and government attempts to eradicate slums in these cities are juxtaposed. In like manner, the slums problems and the experiences of slums eradication in Nigeria as a whole are contrasted against the experiences of other developing countries.

The study is retrospective in approach and therefore employs secondary source materials: the national housing policy statement and demographic and housing census data. These data were obtained from the National Bureau of Statistics of Nigeria and the Federal Ministry for Lands, Housing and Urban Development. Other materials include reports published by international agencies (the UN, the UN-Habit, and the World Bank) that are collaborating with governmental organisations to improve slum conditions in Nigeria, publications by NGOs (the Cities Alliance, the Amnesty International, the Centre on Housing Rights and Eviction - COHRE, The integrated Regional Information Networks - IRIN and the Social and Economic Rights Action Centre - SERAC) who are concern with slum problems and eradication practices in Nigeria, and local newspapers reports on slums issues and the response of government authorities. These materials were retrieved from the websites of the publishers.

\section{Slum Problems and the Response of International Agencies and National Governments}

Since 1976, following the United Nations Conference on Human Settlements in Vancouver, slums problems have engendered international debates and various responses by international organisations, non-governmental organisations and the national governments of various countries. Accordingly, the international agencies (the European Union, UN-Habitat, the Cities Alliance, and the World Bank) have formed a synergy with local authorities, national governments, and non-governmental organisations (NGOs), to fast track slums improvement programmes around the world. The Cities Alliance have emphasised the need to recognise the place of slums in developing societies and to undertake its improvement through partnership. Thus, a successful slum upgrading programme should embrace a number of principles: 1) government should accept and acknowledge slums and their importance; 2) it is assumed that political will and leadership makes slums upgrading possible; 3) government should include the slums in the city's plans, mobilise partners and provide security of tenure; 4) in planning for slum improvement, relevant authorities should plan with, and not for, the slum communities; 5) government is expected to ensure continuity of efforts over time and institutionalise the programme; 6) government is expected to allocate budget, design subsidies, mobilise public and non-public resources; 7) there should be alternatives to new slums formation and this require the upgrading of slums and preventing the formation of new ones; and 8) government is expected to invest in community infrastructure (Cities Alliance, 2013). 
In line with the charter of the Cities Alliance, countries around the world have devised strategies for the upgrading of slums. One of such strategies involves the use of a bottom-up approach as opposed to top-down; it also involves the empowering of local government authorities and agencies to implemented slum upgrading programmes. Some countries that have achieved success on the basis of employing this strategy include among others, Indonesia, Brazil, Jordan, India, Tunisia and the Philippines (World Bank and UN-Habitat, 1999 p. 3). For these countries, the key ingredient for success was the political commitment of national and local government authorities to the bottom-up community-based strategies (World Bank and UN-Habitat, ibid).

Elsewhere in the Xi'an district of China, a strategy was devised, which enabled the community to change the approach of slum improvement programme, from top-down to bottom-up. This change helped the people of Xi'an district to achieve: one, increased conservation of heritage buildings and massive redevelopment of traditional quarters; two, it helped the residents to sustain the fight for their right to the place; three, it reduce the likelihood of displacing the residents and disrupting neighbourhood networks; fourthly, the collective and indigenous wisdom of the residents was deployed in the decision making process and this prevented the failure of the local regeneration plan; and lastly, their fight eventually compelled the district government to incorporate the retention of their ways of living and business in the revised redevelopment plan (Zhai \& Ng, 2013).

In Africa, Egypt and South Africa have made progress in the upgrading of slums (Cities Alliance, 2008). In the case of Egypt, the authorities adopted a participatory development strategy with the objective of: "defining the framework for improving living conditions in informal settlements; providing a mechanism for managing and monitoring the upgrading activities in each locality; coordinating the capacity development of local administration staff working with the governorate and districts; facilitating trust-building activities between local administrations and residents of informal areas, enhancing their affiliation and sense of ownership of development as key partners; and coordinating the replication of best practices of dealing with informal areas through the governorate" (Cities Alliance, 2008, p. 13).

In the case of South Africa, a sustainable livelihoods approach for slum improvement was adopted. This approach has a number of elements, including: "commitment to in-situ development as a first priority; in-depth community surveys as the source of in-depth information on community circumstances, and subsequent tailoring of development interventions; close consultation with households, and extension of choice over house types and levels of services to ensure affordability; strengthening social capital by the promotion of clubs and societies, such as youth and women's groups, or social and recreational groups; access to programmes on basic education skills training, employment strategies, and how to access resources for learning" In addition to these advantages, the sustainable livelihoods approach devised in South Africa allows for the "use of sustainable urban design - maximising use of layout and topography and orientation of properties, unit mix, size, and distribution; passive thermal design of individual units, as well as insulation and ceiling installation; encouraging businesses in and around residential areas; facilitating the provision of financial and technical services to businesses at their various stages of development; supporting public works programmes and the use of local labour; the use of community development workers to motivate and organise community development initiatives and information gathering" (Cities Alliance, 2008, p. 24, 25).

In regard to policy framework, Nigeria is seen to be making some efforts; however, the country is currently faced with a challenge of overcoming a backlog of 17 million housing units (Pepple, 2012). This figure is a mere guess by the Nigerian authorities but it may not be far from the actual. As a result of this backlog, slum housing conditions have become prevalent. The condition of slums in some selected cities of Nigeria (see Figure 1) shows the real situation that slums dwellers in Abuja, Jos, Port-Harcourt and Lagos are confronted with. The experiences of slum dwellers in these cities along with the response of governmental authorities will be subsequently examined. Nigeria has formulated a number of policies to address housing problems and urban development challenges. The key policy statements include the National Housing Policy (1991, revised in 2006 and 2012); the Urban and Regional Planning Law (1992); and the Urban Development Policy (2012). With regard to housing, these policy statements (National Housing Policy 2006, 2012) contain a number of strategies for the prevention of slums and the improvement of existing blighted residential areas. The policy statements are proactive, requiring the federal, state and local government authorities to provide residential site-and-services layout for new housing. The policies require government authorities in different cities of Nigeria to provide serviced plots at subsidised cost to house-building companies and individuals to build new houses. This policy strategy was promoted by the World Bank and United Nations in developing countries so that the poor and low-income households would have access to adequate housing (Mayo \& Gross, 1978). In Nigeria, the attempts to implement site-and-services have experienced a number of challenges: firstly, the process of land acquisition is often shrouded in problems that create implementation delay. Secondly, the policy is often affected by bureaucratic issues and delay in the 
provision of services. Lastly, whereas the site-and-services scheme is widely considered as housing option for the poor and low-income households (Greene, 2010), it is, however, not often implemented to benefit such category of people in Nigeria (Aribigbola \& Ayeniyo, 2012; UN-Habitat, 2001).

With respect to the improvement of slum conditions, the policy statements (National Housing Policy 2006, 2012; and the Urban Development Policy, 2012) propose the use of in situ upgrading, which is otherwise, described as the adaptive approach (Greene, 2010; World Bank 2008). To achieve this, the relevant governmental agencies at the local level are expected to network with international agencies, local private finance institutions, cooperative societies, NGOs, and Community-Based Organisations (CBOs) to design and implement slum upgrading programmes. Available evidences, which will further be examined in subsequent discussions, indicate that the use of adaptive approach is experiencing implementing challenges in Nigerian cities. This is not the case in other developing countries such as the Philippines, Tanzania, Mauritania, Vietnam, Brazil (World Bank, 2008), Thailand, Egypt, Namibia and South Africa (Greene, 2010), where considerable success has been recorded in the implementation of adaptive approach. In these countries, the factors that influence the success rates include: firstly, the adoption of innovative financing approach which encourage households to save towards the improvement of their houses and the typical examples are South Africa and Namibia. Collective or community financing is also used in Namibia, South Africa, and the Philippines. Secondly, there is always a proper enumeration of houses and households affected in particular community before the commencement of upgrading programme. Lastly, the decentralisation of implementation process, community-based planning methodology, local-level partnership and participation of stakeholders has led to the success recorded in all the above listed countries (Greene, 2010).

There are on-going efforts toward the improvement of slums conditions in Nigerian cities. As of 2012, the Federal Ministry of Lands, Housing and Urban Development, working under the Millennium Development Goals (MDGs) programme, executed a total of 259 projects in various parts of the country at the cost of $\$ 4$, $892,299,505.75$ (US $\$ 311,611,461.82$ ). The projects consisted of public buildings and utilities (69 projects), construction/upgrading of access roads (56 projects), slum electrification (64 projects), and water and sanitation (70 projects) (Pepple, 2012b). At the state and local government levels, the World Bank has provided a loan facility through the federal government, for the implementation of community and social development projects. The projects (which include: health care facilities, primary school, electrification, water supply, erosion control, road and drainage) are targeted at slums, new residential sites and rural communities. As of 2012, the programme was active in 26 out of 36 States and 310 out of 774 Local Government Areas were involved. Over 1600 community development plans were being implemented, consisting of 3435 micro projects, of which more than $50 \%$ were completed as of 2012 (World Bank, 2012). In like manner, the UN-Habitat, in partnership with the African Development Bank and the Federal Government of Nigeria designed a programme for the supply of water and the improvement of sanitation conditions in communities that are were experiencing such challenges. The city of Jos in North-Central Nigeria is the sole beneficiary of the pilot programme which was implemented in three informal settlements (UN-Habit, 2008 pp. 20-21).

\section{Analysis of Slum Eradication Practices in Some Selected Nigerian Cities}

The preceding discussion indicates that slum improvement schemes are being implemented in Nigerian cities. In spite of this, the slum situation remains a big concern in most cities, as previously confirmed. And more worrisome is the action of government authorities in different cities, which is evidently aggravating the difficulty of slum dwellers. The key issues arising from the examination documents collected are categorised in following themes:

\subsection{The Ignoring of Slum Conditions to Develop on a Larger Scale}

The appropriate approach for the prevention of slums is the use of proactive measures. To be proactive is to "manage the process of urban expansion so that cities can organise, orient, and initiate their response to the multitude of challenges and opportunities posed by their urban future (World Bank, 2008 pp. 29-30). The documentary evidence examined suggests that Nigerian authorities are reluctant to adopt this approach and the consequence is the growth of shanties and shacks. In Abuja for instance, the residents of slums are usually allowed to acquire land from the native people who are waiting for resettlement by government, and this allows them to illegally squad on land that belongs to the federal government. As of 2004, there were 27 squatter settlements in different parts of the Federal Capital Territory (FCT) and their combined development covered a land area of 2412 hectares (SERAC, 2006 pp.28-29).

The situation in Jos is different to that of Abuja in the sense that the residents of slums often acquire their land legally from the native owners. However, the purchasers would usually not formalise the transaction at the land 
registries. In addition, the purchasers often undertake development on the land without obtaining development permits from the local planning and development control agencies. As of 2004, a total of 25 slums areas were recommended for renewal (Dung-Gwom, 2007) and the government in Jos responded by updating the master plan for the city and also designed a strategic plan for its implementation (Government of Plateau State, 2008a; 2009). However, the full scale implementation of the strategic plan was yet to commence as of 2012 but the government was focused on the expansion of inner city roads and opening of new ones: nine contracts for such projects were awarded in 2008 (Government of Plateau State, 2008b p. 43) and 10 other projects were awarded in 2013 (Alao, 2013).

The neglectful attitude of governmental authorities to slums in Jos is similar to that of Port Harcourt. Whereas as in Jos, the slums residents are marginalised around open mining ponds and rocky areas, those in Port Harcourt reside in marshy waterfronts. In 2009, the government in Port Harcourt declared that waterfront areas were porous, full of criminal activities, and causing threat to security within the state. The government decided to clear all the waterfront shanties and nine settlements were recommended for demolition (Nnanna, Onah \& Onoyume, 2009). In Lagos, most of the slums are situated around the waterfronts and marshy areas, and some houses are even constructed on top of water such as the Makoko settlement (figure 1). In 2006, the State Government in collaboration with the World Bank identified nine of Lagos' largest slums for upgrading (IRIN, 2006).

The slums settlements in the cities under consideration appear to have one issue in common: the residents are often deprived and excluded from access to public infrastructure, facilities and services. To illustrate this with example of getting access to safe drinking water in Mokoko slum of Lagos for instance, there are several communal water points. But people may have to paddle their canoe $3 \mathrm{~km}$ to get there. They then pay about 10 (US\$0.06) for a 10 litre bucket (Guardian News and Media Limited, 2011). In like manner, access to safe drinking water is unstable in most of the slums settlements of Abuja. The slum resident mainly relies upon 'mairuwa' (water vendor) who sell water that is fetched from the commercial boreholes or from distant rivers and streams. In some areas of Abuja, 50 litres water-can will cost $\$ 50$ (US\$0.31) (Uzondu, 2013). Walker (2013) found that a large family in Abuja may need around 200litres (about 10 water-cans) every day, and that adds up to about US $\$ 486$ every year. This often put pressure on poor and low-income households that live on an average of US\$2 a day. In Jos, the West Africa Wash Journalists Network (2012) cites a case of Tudun Wada and Hwolshe slum areas to explain that residents urinate and defecate in a stream at one end of the town, and fetch the water from the same stream at the other end to use in their houses. These evidence all point to the fact that government authorities are exhibiting neglectful attitude towards the formation of slums.

\subsection{Eviction of Slum Residents}

In 2006, Nigeria was ranked third among the worse violators of housing rights by the Geneva-based CORHE (CORHE, 2009). From 2000 to 2011, more than two million people have been forcibly evicted from their homes in different parts of Nigeria. And most of those affected were already marginalised in slums and many had lived their lives without access to clean water, sanitation, adequate health care or education (Amnesty International, 2011).There are two key issues of concern about force eviction in Nigeria: firstly, the residents are often not given adequate notice of eviction or even evicted without prior notice. For example, about 19,000 people were forcibly evicted from their homes in August 2009 at the Njemanze waterfront in Port Harcourt. These evictions were carried out without adequate notice (Amnesty International, 2011). Further, the Amnesty International (2011) announced via a press release published in its website that: "in April 2005, houses, churches, and medical clinics were demolished in the community of Makoko, Lagos. About 3,000 people lost their homes. In Abuja, the federal authority usually notifies the indigene residents of its plan to displace and resettle them. This is so because the Federal Capital Territory was relocated from Lagos to Abuja and the government promised to resettle the native residents of the area. This is not the case with non-indigene residents who squad on land that belong to the federal government. For this category of people, the government usually evict them on short notice (SERAC, 2006). 


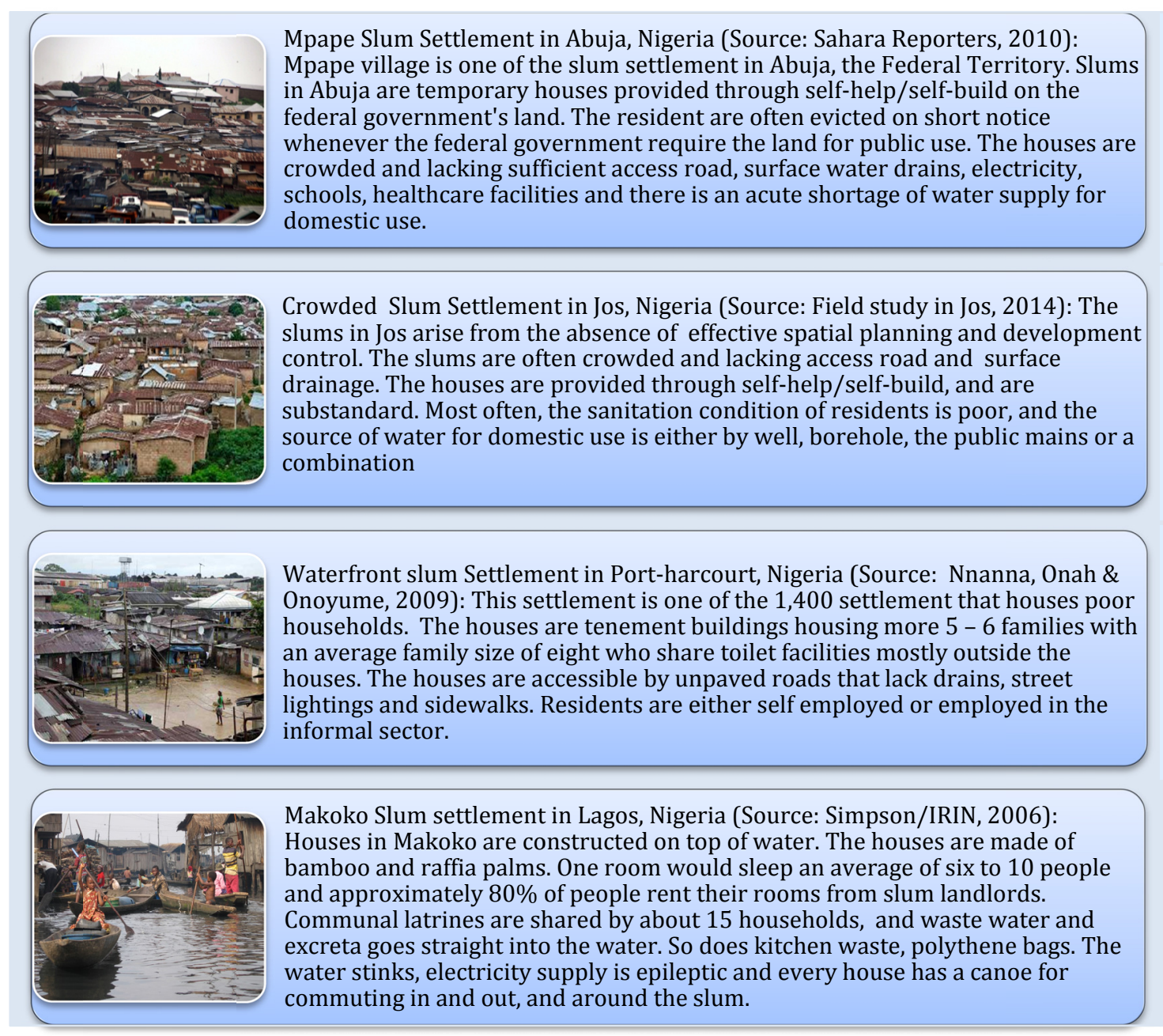

Figure 1. An illustration of slum conditions in some selected Nigerian cities

The second issue that often arise from forced eviction is the inadequate compensation to the affected households or the provision of alternative accommodation. In Abuja, the indigene residents are usually resettled to an alternative settlement but the non-indigene residents are not. For instance, SERAC (2006 p.10) documents that: "between July and September 2000, demolitions were carried without adequate compensation or resettlement; an estimated 50,000 residents were displaced from their homes without alternative accommodation". The government in Lagos has made attempts to compensate displaced slum residents. However, the compensations were delayed; the case of those evicted from Makoko is an example (Sessou, 2013). More so, the affected people were not compensated adequately and studies (Agbola \& Jinadu, 1997) show that most of those resettled to alternative accommodation were worse housed than they were before the eviction.

\subsection{The Demolition of Slum Houses}

Instead of improvement, the authorities in Nigeria would prefer to demolish slum houses and in the process, they inflict untold hardship on the affected residents. The authorities in Abuja appear to be notorious for this practice. This assertion is substantiated in CORHE's report (2009 pp. 40-41), which indicates that demolitions have occurred in 34 settlements from 2003 to 2007. The justification that the authorities gave was that there was a need to restore the master plan of the Federal Capital Territory. Interestingly, the state government authorities in Lagos, (SERAC, 2006 p. 10), Jos (Dung-Gwom, 2007a) and Port Harcourt (Amnesty International, 2011) have justified their actions or planned action on the need for urban renewal and the restoration of the master plan. These reasons could as well be interpreted to mean a failure on the part of the relevant authorities to properly manage urban growth, prevent the occurrence of slums or to upgrade those settlements that have already turned into shanties with minimal interferences to the livelihood of the residents. 


\subsection{The Use of Violent Means to Evict the Residents of Slums}

There is a practice of employing violent means to evict residents of slums. This process often results in the loss of lives and causes injuries to people and damages to properties. A typical scenario is documented in Durumi I, II, III, Kado and some parts of Garki in Abuja (SERAC, 2006 p.38). In this cases, seven people who were trying to resist the demolition of their houses were killed including a pregnant woman and others were injured (SERAC, 2006).

Writing about the experience in Port Harcourt, the Amnesty International (2011) observed that: in one settlement, the demolitions were accompanied by the use of force by Nigerian security forces. Twelve protesters were shot and injured in Bundu waterfront in October 2009. The Amnesty International documents that six people were killed. There are more than 40 waterfront settlements in Port Harcourt and they make up some of the city's most densely populated areas. The Amnesty International (2011) has raised concern that if the State Government authorities in Port Harcourt "continue with the planned demolitions of all the remaining waterfront settlements without first implementing adequate human rights safeguards, more than 200,000 people will be at risk of losing their homes and livelihoods". In like manner, the Amnesty International (2011) documents that: protesters were beaten and injured by law enforcement officials during the demolition of Makoko slum in Lagos. Oseni (2013) corroborates this evidence and adds that about 100,000 people lost their houses as a result of the demolition. All this evidence calls for a policy that would prevent the use of violent means to evict the residents of slums.

\section{Conclusions and Implication for Policy}

This study was set out to review the state of urban slums and government's response to the slums problems in some selected cities (Lagos, Port Harcourt, Abuja and Jos) in Nigeria. The data collected and examined affirms that the slumming process in the four cities is significantly accounted for by rising urbanisation. In Lagos and Port Harcourt cities the urbanisation appear to be linked to the industrialisation process but this is not the case in Abuja and Jos. However, some factors were found to be common in the slumming process of the four cities such as: One, the growing population which is increasing the demand for urban services. Two, there is acute shortage in the supply of adequate housing for the low-come and poor households. Lastly, there is a failure on the part of government authorities to properly manage growth and expansion in the four cities.

The information collected and examined in regard to the approach employed to eradicate slums by the Federal Government authorities in Abuja and the State Government authorities in Lagos, Port Harcourt and Jos suggest that: the authorities have the tendency to ignore slum conditions to develop in a large scale before the introduction of corrective measures. As this appears to be the practice in the four cities, further study could ascertain the situation in other cities of Nigeria. To a greater degree, there is a practice of eradicating slum settlements through force eviction and the demolition of houses. A number of force evictions cases that have occurred in Abuja, Lagos and Port Harcourt cities are brought to focus in this study for illustration. This approach is a clear contravention of the convention which emphasis the use of adaptive approach as against the demolition of slums. A policy is required to address this problem.

The force evictions that have occurred in the cities studied were carried out on short notice and in most instance, the affected residents were not compensated or resettled to alternative accommodation. And where compensations were made, they are found to be inadequate. Lagos city is a typical example where such concern has been raised. These findings suggest that the existing policy framework for the improvement of slum housing in Nigeria is inadequate in the sense that it does not protect the housing rights of slum residents. There is the need for government to review the housing policy and the Land Use Act to incorporate an enforceable statement for the prevention of force eviction on short notice and without the compensation of affected household. Considering that Nigeria operates federalism, the provision of State Government sub-legislation and Local Government by-laws will be essential to support this intention.

This study found that in Abuja, the Federal Capital Territory of Nigeria, the Federal Government authorities are, to some extent, demonstrating a political commitment in the resettlement of indigenous residents to alternative sites and accommodation. This resettlement programme is yearning for empirical study to examine how the resettled households are adapting to their new settlements and houses, and to understand the issues that affect their livelihoods after the resettlement.

The use of violent means to evict slum residents from their houses has been identified as one of the issues affecting slum dwellers in Abuja, Lagos and Port Harcourt. This approach has led to loss of lives and properties. It has caused injuries to affected residents, disrupted businesses from where some of the slum residents earn their incomes and is capable of reinforcing urban poverty. More so, evictions of this nature are a clear indication of the failure of government authorities to engage with the residents of slums in a dialogue prior to their eviction. 
Elsewhere in Namibia, South Africa and the Philippines, the authorities have devised a methodology where the government will partner with slum residents, NGOs, and financial institutions to jointly participate in financing and the implementation of slum upgrading schemes. The authorities in Nigeria could learn from the experiences of these countries to design a policy framework for local level partnership in the implementation of slum upgrading schemes. This will possibly change the trends of force evictions that are presently being experienced in some of the cities studied.

\section{References}

Affordable Housing Institute. (2008). History of US Public Housing: Part 1-6. Retrieved July 22, 2013, from http://affordablehousinginstitute.org/blogs/us/2008/09/history-of-us-public-housing-part-1-the-puritans.html

Agbola, T., \& Jinadu, A. M. (1997). Forced eviction and forced relocation in Nigeria: The experience of those evicted from Maroko in 1990. Environment and Urbanization, 9(2), 271-288. http://dx.doi.org/10.1177/095624789700900214

Akinbamijo, O. B. (2012). Urbanization and Socio Economic Position Analysis - An Approach to Housing and Health Relationships in Residential Districts of Nigerian Cities. The Built \& Human Environment Review, 5, $1-13$.

Alao, O. (2013). Plateau signs contracts for Jos flyover, 9 other projects Jos. Daily Trust Online, Thursday, 14 February.

Amnesty International. (2010). 'Just move them', Forced evictions in Port Harcourt, Nigeria. Amnesty International Publications, International Secretariat, United Kingdom.

Amnesty International. (2011). Eyes on Nigeria. Retrieved June 28, 2013, fromhttp://www.eyesonnigeria.org/EON_Evictions.html

Aribigbola, A., \& Ayeniyo, O. I. (2012). Site-and-services as a strategy for achieving adequate housing in Nigeria in the $21^{\text {st }}$ century.International Journal of Humanities and Social Sciences, 2(2), 126-132.

Baker, K. (2001, September 30). The First Slum in America, The New York Times. Retrieved fromhttp://www.nytimes.com/2001/09/30/books/the-first-slum-in-america.html

Bala, P. A. (2009). Urban Concentration and Economic Growth: checking for specific regional effects. CORE Discussion Paper, (38), 1-43.

Begum, H., \& Moinuddin, G. (2010).Spatial Dimension of Social Exclusion. An Imperial Investigation into the Relationship of Housing and Social Exclusion in the Slums of Dhaka City. Management Research and Practice, 2(3), 314-328.

Centre on Housing Rights and Eviction. (2012).For evictions - a manual for action and human rights. COHRE Africa, Lagos, Nigeria.

Centre on Housing Rights and Evictions. (2009). Global Forced Evictions Survey - 2007-2008. Geneva, Switzerland.

Chang, T. (2009).Improving Slum Conditions with Public-Private Partnerships. Panorama. Retrieved June 26, 2013, from http://www.design.upenn.edu/files/Panorama09_05_ImprovingSlum_Chang.pdf

Cities Alliance. (2008). Slum upgrading: up close experiences of six cities. Washington, D.C

Cities Alliance. (2011). City Development Strategy: A Conceptual Framework. Cities Alliance Discussion Paper 1.

Cities Alliance.(2013). A Policy Framework for a Slum Upgrading Programme. Retrieved June 24, 2013, from http://www.citiesalliance.org/su-policy

Davis, M. (2004). Planet of Slums. New Left Review, 26, 5-34.

Davis, M. (2006). Planet of Slums. Verso, London. http://dx.doi.org/10.1111/j.1540-5842.2006.00797.x

Diniejko, A. (2012). Slums and Slumming in Late-Victorian London. Literature, history, \& culture in the age of Victoria, the Victorian Web. Retrieved July 22, 2013, from http://www.victorianweb.org/history/slums.html

Dung-Gwom, J. Y. (2007).Urban Renewal in Jos - Bukuru Metropolis. The Nigerian Institutions of Estate Surveyors and Valuers, MCPD Workshop On: Housing Delivery, Urban Renewal in Jos - Bukuru Metropolis Problems and Prospects. Leadership Institute Jos, Plateau State, October, 25th.

FinMark Trust Year Book. (2011). Housing Finance in Africa: A review of some of Africa's housing finance 
markets. The Centre for Affordable Housing Finance in Africa a division of the FinMark Trust, South Africa.

FRN. (1992). The Nigerian Urban and Regional Planning Act 1992.

FRN. (2012a). National Housing Policy. The Federal Ministry of Lands, Housing and Urban Development, Abuja.

FRN. (2012b). Nigerian Poverty Profile Report 2010. The National Bureau of Statistics, Abuja.

FRN. (2012c). LSMS - Integrated Surveys on Agriculture: General Household Survey Panel 2010/11. A Report by the National Bureau of Statistics in Collaboration with the Federal Ministry of Agriculture and Rural Development and the World Bank.

FRN. (2012d).The National Urban Development Policy. The Federal Ministry of Lands, Housing and Urban Development, Abuja.

FRN. (2013). Nigeria over 167million population: Implications and Challenges, National Population Commission, Abuja.

Government of Plateau State (2008a).A Quarterly Publication of the Ministry of Information and Communication, Jos. Plateau State Today, 1(2).

Government of Plateau State.(2008b).Four year strategic plan for urban development and housing in Plateau State. Jos, Nigeria.

Greene, M. (2010). Literature Review: Main Policy and Programmatic Approaches for Slum Upgrading. Desk Review of National Policy Reforms and Programmatic Approaches to Slum Upgrading and Prevention and Case Study Template for In-Country Work.

Integrated Regional Information Networks. (2013).Nigeria: Lagos, the mega-city of slums. IRIN humanitarian news and analysis, a service of the UN Office for the Coordination of Humanitarian Affairs.

Mayo, S. K., \& Gross, D. J. (1978). Sites and Services-and Subsidies: The Economics of Low-Cost Housing in Developing Countries. The World Bank Economic Review, 1(2), 301-335. http://dx.doi.org/10.1093/wber/1.2.301

Ooi, G. L., \&Phua, K. H. (2007).Urbanization and Slum Formation. Journal of Urban Health: Bulletin of the New York Academy of Medicine, 84(1), 27-34. http://dx.doi.org/10.1007/s11524-007-9167-5

Pepple, A. I. (2012a). Nigeria: Progress on improving the lives of slum-dwellers over the decade 2000-2010.Presentation by the Honourable Minister of Lands, Housing and Urban Development of Nigeria at the International Conference on Making Slums History a worldwide challenge for 2020, Rabat, Morocco, November 26 - 29.

Pepple, A. I. (2012b). Federal Ministry of Lands, Housing and Urban Development. Presentation at the 2012 Ministerial Platform, Abuja, May $15^{\text {th }}$.

Potts, D. (2010). Challenging the myths of urban dynamics in sub-Saharan Africa: evidence from Nigeria, Environment, Politics and Development Working Papers Series, 2011, paper \#39, Department of Geography, Kings College London.

Potts, D. (2012). Whatever happened to Africa's rapid urbanisation? Africa Research Institute, London.

Ryan, V. (2010). Poverty and slums. World Association of Technology Teachers. Retrieved July 26, 2013, from http://www.technologystudent.com/PDF_PSE1/slums1a.pdf

Sessou, E. (2013, May 6). LSHA seeks new houses for displaced Ogba residents. Vanguard Nigeria, 30-31.

Social and Economic Rights Action Centre. (2006). Pushing Out the Poor: Forced Evictions under the Abuja Master Plan. SERAC, Lagos, Nigeria.

Social and Economic Rights Action Centre. (2008). Forced evictions as urban planning in Abuja, Nigeria. Social and Economic Rights Action Centre, Lagos, Nigeria.

UN-Habitat. (2007). What are slums and why do they exist? Twenty first session of the Governing Council, April 16-20, Nairobi, Kenya.

UN-Habitat. (2008). State of the World's cities 2006/07.United National Human Settlements Programme, Nairobi, Kenya.

UN-Habitat. (2009). Water for African Cities Programme Phase II. United Nations Human Settlements Programme, Nairobi, Kenya. 
UN-Habitat. (2010a). The state of African cities - Governance, inequality and urban land market. United Nations Human Settlements Programme, Nairobi, Kenya.

UN-Habitat. (2010b). Urban trends: 227 million escape slums. Bridging the urban divided. State of the world's cities 2010/2011.

UN-Habitat. (2012). The state of the world's cities 2012/2013. Property of cities, World Urban Forum Edition. United National Human Settlements Programme, Nairobi, Kenya.

United Nations. (2013). Over 200 million escape slums but overall number still rising, UN report finds. UN News Centre, New York. Retrieved June 24, 2013, from http://www.un.org/apps/news/story.asp?NewsID=34119\&

Uzondu, J. (2013). Booming water vending business. Nigerian News World Magazine Limited, Abuja.

Venard, J. L. (1995). Urban Planning and Environment in Sub-Saharan Africa. UNCEDPaper no. 5 (AFTES).

Walker, A. (2013). The water vendors of Nigeria, Story from BBC News, Abuja, Nigeria. Retrieved from $\mathrm{http}: / /$ news.bbc.co.uk/go/pr/fr/-/1/hi/sci/tech/7867202.stm

World Bank and UN-Habitat. (1999). Cities Alliance for Cities without slums: Action plan for moving slum upgrading to scale. Retrieved fromhttp://web.mit.edu/urbanupgrading/sponsor/ActionPlan.pdf

World Bank. (1996). African Water Resources. World Bank Technical Paper no. 331, Washington D. C., USA.

World Bank. (2008). Approaches to Urban Slums: A Multimedia Sourcebook on Adaptive and Proactive Strategies. Washington D. C., USA.

World Bank. (2012). Restructuring Paper on a Proposed Project Restructuring of Community and Social Development Project (CSDP) Credit to the Federal Republic of Nigeria. Document of the World Bank Report No: 73378-NG.

World Bank. (2013). Sub-Saharan Africa: Development only. Retrieved from http://data.worldbank.org/region/sub-saharan-africa

Zhai, B., \& Ng, M. K. (2013). Urban regeneration and social capital in China: A case study of the Drum Tower Muslim District in Xi'an. Cities, 35, 14-25. http://dx.doi.org/10.1016/j.cities.2013.05.003

\section{Copyrights}

Copyright for this article is retained by the author(s), with first publication rights granted to the journal.

This is an open-access article distributed under the terms and conditions of the Creative Commons Attribution license (http://creativecommons.org/licenses/by/3.0/). 